\title{
Simple Prediction of the Survival of Follicles in Cryopreserved Human Ovarian Tissue
}

\author{
Theodoros MALTARIS ${ }^{1)}$, Charalampos DRAGONAS ${ }^{1)}$, Inge HOFFMANN ${ }^{1}$, \\ Andreas MUELLER ${ }^{1)}$, Matthias W. BECKMANN ${ }^{1)}$ and Ralf DITTRICH ${ }^{1)}$ \\ 1) University Hospital Erlangen, Department of Obstetrics and Gynaecology, \\ Universitaetsstrasse 21-23, D-91054 Erlangen, Germany
}

\begin{abstract}
This study examines the possible predictive value of the LIVE/DEAD fluorescence viability assay for evaluation of survival of cryopreserved human ovarian tissue. Ovarian tissue from ten patients was examined by LIVE/DEAD viability staining before and after cryopreservation and after freezing in a $-20 \mathrm{C}$ freezer (negative control). After cryopreservation with a slow freezing protocol and cryoprotectant the LIVE/DEAD assay showed $86 \%$ viable follicles (an intact oocyte and at least more than $50 \%$ of the granulosa cells alive), whereas after freezing at $-20 \mathrm{C}$ the survival rate was $67 \%$. The healthy follicular loss after cryopreservation was $4 \%$, whereas with freezing at $-20 \mathrm{C}$, it was $25 \%$. Although this assay overestimates the survival rate of cryopreserved primordial follicles, if the LIVE/ DEAD assay yields greater than approximately $85 \%$ viable follicles, it can be assumed that the follicles in the cryopreserved tissue have maintained their developmental potential and that the tissue is suitable for retransplantation.
\end{abstract}

Key words: Cancer therapy, Cryopreservation, Fertility preservation, Granulosa cells, Transplantation

(J. Reprod. Dev. 52: 577-582, 2006)

A ggressive chemotherapy and radiotherapy in young females with cancer has greatly enhanced the life expectancy of these patients, but these treatments often cause infertility because of massive destruction of the ovarian reserve resulting in premature ovarian failure. These young women have to face years of hormone replacement therapy and the prospect of definite infertility, which causes additional psychological stress [1, 2].

For male patients, semen cryopreservation is an effective and non-invasive technique that has already yielded thousands of successful pregnancies. For women, cryopreservation of oocytes is more difficult to perform because of a

Accepted for publication: March 13, 2006

Published online: June 24, 2006

Correspondence: R. Dittrich

(e-mail: ralf.dittrich@gyn.imed.uni-erlangen.de) higher rate of abnormal spindle and chromosome configuration $[3,4]$. Other options, also with limited applications, are ovarian transposition before radiation exposure and treatment with GnRH-analogs $[5,6]$. The most promising method, however, is cryopreservation of ovarian tissue before oncological treatments because of the large number of primordial oocytes that survive the freeze/thawing procedure [7-9]. Although only two pregnancies have been achieved so far $[10,11]$, cryopreservation of ovarian tissue is being offered by many groups due to its future therapeutic potential [12-16].

The aim of our study was to examine the predictive value of the LIVE/DEAD assay for evaluation of the survival of follicles after the freezing/thawing procedure, as it is known, for example, that there is variation in the survival rates 
Table 1. Survival of follicles assessed by LIVE/DEAD viability assay before and after cryopreservation and after freezing in a $-20 \mathrm{C}$ freezer

\begin{tabular}{|c|c|c|c|c|c|c|c|c|c|c|c|c|c|}
\hline \multirow[t]{2}{*}{ Patient diagnosis } & \multirow[t]{2}{*}{ Age } & \multicolumn{3}{|c|}{$\begin{array}{l}\text { Survival count (\%) } \\
\text { (fresh ovarian tissue) }\end{array}$} & \multicolumn{5}{|c|}{$\begin{array}{c}\text { Survival count }(\%) \\
\text { (cryopreserved ovarian tissue) }\end{array}$} & \multicolumn{4}{|c|}{$\begin{array}{c}\text { Survival count }(\%) \\
(-20 \text { C frozen, neg. control) }\end{array}$} \\
\hline & & $\begin{array}{l}\text { Complete } \\
\text { follicle }\end{array}$ & $\begin{array}{c}\text { Oocyte + } \\
>50 \% \\
\text { granulosa }\end{array}$ & $\begin{array}{c}\text { Oocyte }+ \\
<50 \% \\
\text { granulosa }\end{array}$ & Dead & $\begin{array}{l}\text { Complete } \\
\text { follicle }\end{array}$ & $\begin{array}{c}\text { Oocyte + } \\
>50 \% \\
\text { granulosa }\end{array}$ & $\begin{array}{c}\text { Oocyte + } \\
<50 \% \\
\text { granulosa }\end{array}$ & Dead & $\begin{array}{l}\text { Complete } \\
\text { follicle }\end{array}$ & $\begin{array}{c}\text { Oocyte + } \\
>50 \% \\
\text { granulosa }\end{array}$ & $\begin{array}{c}\text { Oocyte }+ \\
<50 \% \\
\text { granulosa }\end{array}$ & Dead \\
\hline Anal cancer & 29 & $\begin{array}{c}18 \\
(43 \%)\end{array}$ & $\begin{array}{c}20 \\
(47 \%)\end{array}$ & $\begin{array}{c}4 \\
(10 \%)\end{array}$ & 0 & $\begin{array}{c}15 \\
(38 \%)\end{array}$ & $\begin{array}{c}21 \\
(52 \%)\end{array}$ & $\begin{array}{c}3 \\
(8 \%)\end{array}$ & $\begin{array}{c}1 \\
(2 \%)\end{array}$ & $\begin{array}{c}10 \\
(32 \%)\end{array}$ & $\begin{array}{c}10 \\
(32 \%)\end{array}$ & $\begin{array}{c}9 \\
(30 \%)\end{array}$ & $\begin{array}{c}2 \\
(6 \%)\end{array}$ \\
\hline Hodgkin's disease & 27 & $\begin{array}{c}23 \\
(50 \%)\end{array}$ & $\begin{array}{c}19 \\
(41 \%)\end{array}$ & $\begin{array}{c}4 \\
(9 \%)\end{array}$ & 0 & $\begin{array}{c}21 \\
(46 \%)\end{array}$ & $\begin{array}{c}20 \\
(43 \%)\end{array}$ & $\begin{array}{c}4 \\
(9 \%)\end{array}$ & $\begin{array}{c}1 \\
(2 \%)\end{array}$ & $\begin{array}{c}15 \\
(32 \%)\end{array}$ & $\begin{array}{c}17 \\
(38 \%)\end{array}$ & $\begin{array}{c}10 \\
(23 \%)\end{array}$ & $\begin{array}{c}3 \\
(7 \%)\end{array}$ \\
\hline Hodgkin's disease & 17 & $\begin{array}{c}28 \\
(45 \%)\end{array}$ & $\begin{array}{c}27 \\
(44 \%)\end{array}$ & $\begin{array}{c}7 \\
(11 \%)\end{array}$ & 0 & $\begin{array}{c}27 \\
(44 \%)\end{array}$ & $\begin{array}{c}24 \\
(39 \%)\end{array}$ & $\begin{array}{c}10 \\
(17 \%)\end{array}$ & 0 & $\begin{array}{c}15 \\
(28 \%)\end{array}$ & $\begin{array}{c}27 \\
(50 \%)\end{array}$ & $\begin{array}{c}10 \\
(18 \%)\end{array}$ & $\begin{array}{c}2 \\
(4 \%)\end{array}$ \\
\hline Ovarial cancer & 37 & $\begin{array}{c}15 \\
(42 \%)\end{array}$ & $\begin{array}{c}18 \\
(50 \%)\end{array}$ & $\begin{array}{c}3 \\
(8 \%)\end{array}$ & 0 & $\begin{array}{c}16 \\
(52 \%)\end{array}$ & $\begin{array}{c}12 \\
(39 \%)\end{array}$ & $\begin{array}{c}2 \\
(6 \%)\end{array}$ & $\begin{array}{c}1 \\
(3 \%)\end{array}$ & $\begin{array}{c}17 \\
(28 \%)\end{array}$ & $\begin{array}{c}26 \\
(41 \%)\end{array}$ & $\begin{array}{c}17 \\
(28 \%)\end{array}$ & $\begin{array}{c}2 \\
(3 \%)\end{array}$ \\
\hline $\begin{array}{l}\text { Chronic myelo- } \\
\text { blastic leukemia }\end{array}$ & 12 & $\begin{array}{c}28 \\
(43 \%)\end{array}$ & $\begin{array}{c}29 \\
(45 \%)\end{array}$ & $\begin{array}{c}8 \\
(12 \%)\end{array}$ & 0 & $\begin{array}{c}26 \\
(44 \%)\end{array}$ & $\begin{array}{c}22 \\
(37 \%)\end{array}$ & $\begin{array}{c}11 \\
(19 \%)\end{array}$ & 0 & $\begin{array}{c}14 \\
(23 \%)\end{array}$ & $\begin{array}{c}28 \\
(45 \%)\end{array}$ & $\begin{array}{c}18 \\
(29 \%)\end{array}$ & $\begin{array}{c}2 \\
(3 \%)\end{array}$ \\
\hline Teratocarcinoma & 17 & $\begin{array}{c}24 \\
(54 \%)\end{array}$ & $\begin{array}{c}17 \\
(39 \%)\end{array}$ & $\begin{array}{c}3 \\
(7 \%)\end{array}$ & 0 & $\begin{array}{c}24 \\
(49 \%)\end{array}$ & $\begin{array}{c}21 \\
(43 \%)\end{array}$ & $\begin{array}{c}4 \\
(8 \%)\end{array}$ & 0 & $\begin{array}{c}14 \\
(32 \%)\end{array}$ & $\begin{array}{c}15 \\
(33 \%)\end{array}$ & $\begin{array}{c}15 \\
(33 \%)\end{array}$ & $\begin{array}{c}1 \\
(2 \%)\end{array}$ \\
\hline $\begin{array}{l}\text { Non Hodgkin's } \\
\text { disease }\end{array}$ & 17 & $\begin{array}{c}22 \\
(47 \%)\end{array}$ & $\begin{array}{c}17 \\
(36 \%)\end{array}$ & $\begin{array}{c}8 \\
(17 \%)\end{array}$ & 0 & $\begin{array}{c}16 \\
(37 \%)\end{array}$ & $\begin{array}{c}18 \\
(42 \%)\end{array}$ & $\begin{array}{c}9 \\
(21 \%)\end{array}$ & 0 & $\begin{array}{c}12 \\
(28 \%)\end{array}$ & $\begin{array}{c}15 \\
(35 \%)\end{array}$ & $\begin{array}{c}12 \\
(28 \%)\end{array}$ & $\begin{array}{c}4 \\
(9 \%)\end{array}$ \\
\hline Dysgerminoma & 18 & $\begin{array}{c}25 \\
(50 \%)\end{array}$ & $\begin{array}{c}19 \\
(38 \%)\end{array}$ & $\begin{array}{c}6 \\
(12 \%)\end{array}$ & 0 & $\begin{array}{c}28 \\
(50 \%)\end{array}$ & $\begin{array}{c}20 \\
(36 \%)\end{array}$ & $\begin{array}{c}7 \\
(12 \%)\end{array}$ & $\begin{array}{c}1 \\
(2 \%)\end{array}$ & $\begin{array}{c}25 \\
(44 \%)\end{array}$ & $\begin{array}{c}17 \\
(30 \%)\end{array}$ & $\begin{array}{c}14 \\
(24 \%)\end{array}$ & $\begin{array}{c}1 \\
(2 \%)\end{array}$ \\
\hline Breast cancer & 31 & $\begin{array}{c}16 \\
(42 \%)\end{array}$ & $\begin{array}{c}17 \\
(45 \%)\end{array}$ & $\begin{array}{c}4 \\
(10 \%)\end{array}$ & $\begin{array}{c}1 \\
(3 \%)\end{array}$ & $\begin{array}{c}16 \\
(38 \%)\end{array}$ & $\begin{array}{c}21 \\
(50 \%)\end{array}$ & $\begin{array}{c}5 \\
(12 \%)\end{array}$ & 0 & $\begin{array}{c}14 \\
(27 \%)\end{array}$ & $\begin{array}{c}18 \\
(35 \%)\end{array}$ & $\begin{array}{c}19 \\
(36 \%)\end{array}$ & $\begin{array}{c}1 \\
(2 \%)\end{array}$ \\
\hline $\begin{array}{l}\text { Non Hodgkin's } \\
\text { disease }\end{array}$ & 18 & $\begin{array}{c}31 \\
(48 \%)\end{array}$ & $\begin{array}{c}26 \\
(41 \%)\end{array}$ & $\begin{array}{c}7 \\
(11 \%)\end{array}$ & 0 & $\begin{array}{c}25 \\
(45 \%)\end{array}$ & $\begin{array}{c}23 \\
(42 \%)\end{array}$ & $\begin{array}{c}7 \\
(13 \%)\end{array}$ & 0 & $\begin{array}{c}21 \\
(35 \%)\end{array}$ & $\begin{array}{c}21 \\
(36 \%)\end{array}$ & $\begin{array}{c}14 \\
(23 \%)\end{array}$ & $\begin{array}{c}3 \\
(6 \%)\end{array}$ \\
\hline Mean \pm SD & $22 \pm 8$ & $\begin{array}{c}23 \pm 5 \\
(46 \pm 4 \%)\end{array}$ & $\begin{array}{c}20 \pm 4 \\
(42 \pm 4 \%)\end{array}$ & $\begin{array}{c}5 \pm 1 \quad 0 \\
(11 \pm 2 \%)(\end{array}$ & $\begin{array}{l}0.1 \pm 0.3 \\
(0.3 \pm 1\end{array}$ & $\begin{array}{l}321 \pm 5 \\
\%)(44 \pm 5 \%\end{array}$ & $\begin{array}{c}20 \pm 3 \\
0)(42 \pm 5 \%)\end{array}$ & $\begin{array}{c}6 \pm 3 \\
(13 \pm 4 \%)\end{array}$ & $\begin{array}{l}0.4 \pm 0.5 \\
(1 \pm 1 \%)\end{array}$ & $\left\{\begin{array}{c}15 \pm 4 \\
(30 \pm 5 \%)\end{array}\right.$ & $\begin{array}{c}19 \pm 6 \\
(37 \pm 6 \%)\end{array}$ & $\begin{array}{c}13 \pm 4 \\
(27 \pm 5 \%)\end{array}$ & $\begin{array}{c}2 \pm 1 \\
(4 \pm 2 \%)\end{array}$ \\
\hline
\end{tabular}

of cryopreserved sperms and embryos from different individuals [17].

A slow freezing protocol with a cryoprotectant was used to cryopreserve human ovarian tissue, which is the present state-of-the-art method used to preserve this type of tissue. Both of the groups that achieved a pregnancy after orthotopic transplantation of cryopreserved ovarian tissue used similar slow cryopreservation protocols in chamber freezing systems. As a negative control to validate the assay, ovarian tissue was frozen without cryopretactants in a $-20 \mathrm{C}$ freezer. This is a method that is considered totally inadequate for freezing of tissue $[18,19]$. Survival of the ovarian tissue before and after cryopreservation and freezing at $-20 \mathrm{C}$ was examined by fluorescent LIVE/DEAD viability assay.

\section{Materials and Methods}

\section{Patients}

10 patients between 12 and 37 (median 17.5 years) years of age were included in this study following informed consent and approval of the local university ethical committee. All patients suffered from malignant diseases (Table 1) and wanted to preserve ovarian tissue for a future pregnancy. A maximum of $5 \%$ of the frozen tissue from each patient was used for our experiments. Prior to cryopreservation, a histological examination of the ovarian cortex was performed to secure a sufficient number of primordial follicles. All patients had an age-related normal follicular distribution.

\section{Cryopreservation protocol}

The ovarian cortex was obtained through an operative laparoscopy by dissecting an area of about $20 \times 10 \times 3 \mathrm{~mm}$ of ovarian tissue antimesenterically. The biopsies were cut into small pieces (about $1 \times 1 \times 1 \mathrm{~mm}$ ) and were equilibrated in ascending aequimolar concentrations of DMSO/propandiol up to a concentration of $1.5 \mathrm{M}$ in steps of $0.25 \mathrm{M}$. The tissue pieces remained in each concentration at $37 \mathrm{C}$ for 7 minutes and at the last concentration of $1.5 \mathrm{M}$ for 30 minutes. The tissue was then placed in special 
cryovials (CTE, Erlangen, Germany) and was loaded into an open freezing system that provides self-seeding (CTE, Erlangen, Germany). The freezing protocol was as follows: $\mathrm{a}$, cool at $-5 \mathrm{C}$ / $\min$ to $-3.8 \mathrm{C} ; \mathrm{b}$, cool at $-1 \mathrm{C} / \mathrm{min}$ to $-5.3 \mathrm{C}$; $\mathrm{c}$, cool at $-0.2 \mathrm{C} / \mathrm{min}$ to $-6 \mathrm{C}$; $\mathrm{d}$, unchanged for $20 \mathrm{~min}$; e, cool at $-0.3 \mathrm{C} / \mathrm{min}$ to $-30 \mathrm{C}$; $\mathrm{f}$, cool at $-0.1 \mathrm{C} / \mathrm{min}$ to $-35 \mathrm{C} ; \mathrm{g}$, cool at $-0.3 \mathrm{C} / \mathrm{min}$ to $-80 \mathrm{C}$; $\mathrm{h}$, cool at -10 $\mathrm{C} / \mathrm{min}$ to $-110 \mathrm{C}$; i, immersion into liquid nitrogen. After storage in liquid nitrogen for at least 1 month the probes were thawed at room temperature. Removal of cryoprotectant was performed in reverse order of the freezing equilibration procedure. The tissue blocks were then cultured in an antibiotic supplemented Medicult IVF Medium (Gück, Berlin, Germany).

Additionally, one tissue piece from each patient was frozen at $-20 \mathrm{C}$ without a cryoprotectant to serve as a negative control (damaged tissue).

\section{LIVE/DEAD assay}

Three ovarian tissue pieces (fresh, cryopreserved, and frozen at $-20 \mathrm{C}$ ) from each patient were examined for estimation of vitality. In order to estimate the number of follicles that survived the freezing/thawing procedure in vitro, a LIVE/ DEAD viability/cytotoxicity assay kit (L-3224, Invitrogen, Paisley, UK) was used with a fluorescence microscope (Fig. 1). The LIVE/DEAD assay is a two-color fluorescence cell viability assay based on simultaneous determination of live and dead cells with two probes that measure the intracellular esterase activity and plasma membrane integrity. It can be used for isolated cells and for tissue probes [20]. This method has been described in detail elsewhere [16]. In brief, we used the kit with a Zeiss fluorescence microscope (IM 35; Zeiss, Oberkochen, Germany) to examine the viability of the frozen-thawed tissue. Live cells are distinguished by the presence of ubiquitous intracellular esterase activity, which is determined by enzymatic conversion of virtually nonfluorescent cell-permeating calcein AM to intensely fluorescent calcein. The polyanionic dye calcein is well retained within live cells, producing an intense uniform green fluorescence in live cells (ex/em 495 $\mathrm{nm} / 515 \mathrm{~nm})$. EthD-1 enters cells with damaged membranes and undergoes a 40-fold enhancement of fluorescence upon binding to nucleic acids, thereby producing a bright red fluorescence in dead cells (ex/em $495 \mathrm{~nm} / 635 \mathrm{~nm}$ ). To perform the

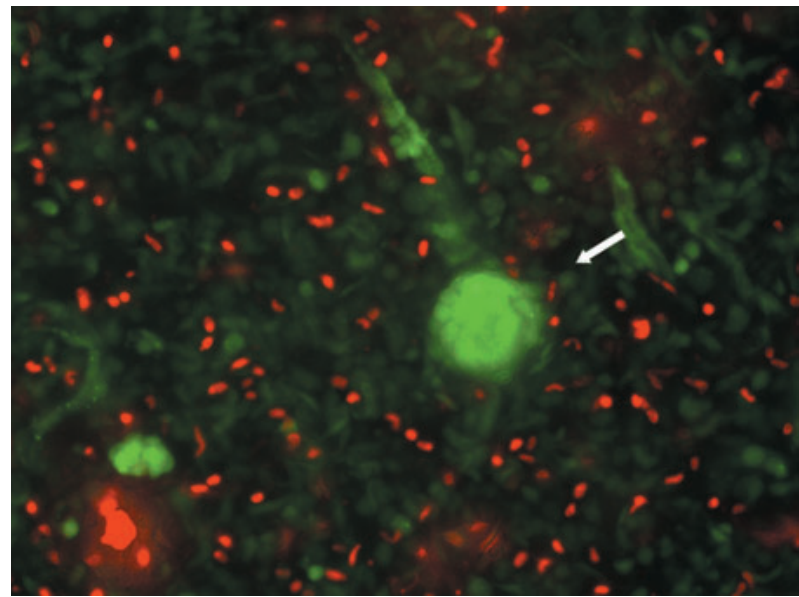

Fig 1. Follicular viability assessment by LIVE/DEAD fluorescence staining (calcein AM and ethidium homodimer-1) of digested ovarian tissue after cryopreservation. Completely viable follicle (green, arrow) and isolated dead granulosa cells in suspension (red) (Leica inverted fluorescence microscope; original magnification $\times 200$ ).

viability assay, we used the following protocol: a, thawed tissue was dissected into pieces as small as possible with a scalpel; b, $3 \mathrm{mg}$ collagenase (Collagenase Type IV, Sigma-Aldrich, Steinheim, Germany) diluted in $3 \mathrm{ml}$ Dulbecco's phosphatebuffered saline (D-PBS) was added to the tissue; c, the samples were left to incubate for approximately two hours at $37 \mathrm{C}$ and the homogenate was stirred periodically every 20 minutes; $d$, the LIVE/DEAD reagent stock solutions were removed from the freezer and allowed to warm to room temperature; e, the reagents were combined by adding $10 \mu \mathrm{l}$ of the $2 \mathrm{mM}$ EthD- 1 stock solution and $5 \mu \mathrm{l}$ of the supplied $4 \mathrm{mM}$ calcein AM stock solution to $10 \mathrm{ml}$ of sterile, tissue culture-grade D-PBS; $f$, the resulting approximately $2 \mu \mathrm{m}$ calcein AM and $4 \mu \mathrm{M}$ EthD-1 working solution was added directly to the samples and left to incubate for 30 minutes in a dark location at room temperature; and $g$, the labelled cells were viewed under a fluorescence microscope.

\section{Statistical evaluation}

SPSS was used for data evaluation. Nominal data were expressed as means \pm SD and were compared using ANOVA. A $P$ value of 0.05 was considered statistically significant. 


\section{Results}

Follicular viability before and after cryopreservation and after freezing in a-20C freezer assessed with the LIVE/DEAD assay

The results of fluorescence staining are given in Table 1.

Before freezing, a total of $46 \pm 4 \%$ (mean \pm SD) of the tissue pieces had intact follicles, $42 \pm 4 \%$ had follicles with an intact oocyte and $>50 \%$ granulose cells alive, and $11 \pm 2 \%$ had an intact oocyte and $<50 \%$ granulose cells alive. Only 1 dead follicle was found.

After cryopreservation with the slow freezing protocol, a total of $44 \pm 5 \%$ of the tissue pieces had intact follicles, $42 \pm 5 \%$ had follicles with an intact oocyte and $>50 \%$ of the granulose cells alive, and 13 $\pm 4 \%$ with intact oocyte and $<50 \%$ granulose cells alive. Dead follicles were very rare $(1 \pm 1 \%)$.

In tissue pieces that were frozen at $-20 \mathrm{C}$ a total of $30 \pm 5 \%$ had intact follicles, $37 \pm 6 \%$ had follicles with an intact oocyte and $>50 \%$ of the granulose cells alive, and $27 \pm 5 \%$ had an intact oocyte and $<50 \%$ of the granulose cells alive. Dead follicles were found more often $(4 \pm 2 \%)$. Compared to the results with fresh ovarian tissue, the healthy follicular loss (intact oocyte and at least more than $50 \%$ of the granulosa cells alive) after cryopreservation was $4 \%$, whereas with freezing at $-20 \mathrm{C}$ it was $25 \%$.

Statistical evaluation showed that there were significant differences in regard to the intact follicles, follicles with less than $50 \%$ of the granulosa cells alive, and dead follicles, whereas there was no statistical difference in the follicles with more than $50 \%$ of the granulose cells alive $(P=$ 0.47).

\section{Discussion}

It is estimated that by 2010 one in every 250 women of reproductive age will be a cancer survivor [21]. Cytotoxic cancer treatment can provoke early menopause and subsequent infertility due to destruction of a significant proportion of the ovarian follicles by chemo- and radiotherapy. Methods used preserve fertility in these young patients include chemoprotection with GnRH-analoga [6] and apoptosis inhibitors [22] before the planned chemotherapy, ovarian transposition before radiation therapy and cryopreservation of oocytes, embryos, or ovarian tissue [23].

However IVF is necessary for cryopreservation of embryos, which is presently a routine method. Many young women do not have a partner to provide sperm at the time of diagnosis or may not be willing to use donor sperm. Often, cancer patients may face serious morbidity if the treatment would be delayed for the IVF procedure, which can take up to 6-8 weeks. IVF before a cancer treatment is also not an option for prepubertal cases. Finally, there are concerns regarding ovarian stimulation in patients with estrogen-sensitive tumors.

For all the above-mentioned cases, one of the most promising interventions is isolation and cryopreservation of ovarian cortical strips followed by future autologous transplantation. Up to now, two pregnancies have been obtained after autotransplantation of cryopreserved ovarian tissue $[10,11]$. Many groups are cryopreserving ovarian tissue for future clinical use [10, 11, 12, 24 26].

The aim of the study was to examine whether the LIVE/DEAD assay can be used as a diagnostic method for survival of follicles in cryopreserved human ovarian tissue. The LIVE/DEAD assay is an easy and relatively cheap method that involves no animal experiments and that requires a minimal amount of tissue. The advantage of the LIVE/ DEAD assay over a histological investigation of frozen-thawed ovarian tissue is that the histological examination would only show a fraction of the cryoinjuries in the nucleus of the surviving follicles and cannot give this type of detailed information for the condition of the granulosa cells.

A LIVE/DEAD assay was used before cryopreservation, after thawing of cryopreserved ovarian tissue, and after thawing of ovarian tissue frozen at $-20 \mathrm{C}$. The tissue frozen at $-20 \mathrm{C}$ was used as a negative control for the LIVE/DEAD assay because it is known that freezing at $-20 \mathrm{C}$ without cryoprotectants is an insufficient freezing procedure [18, 19].

The results of staining with LIVE/DEAD florescent assay dye confirmed that a high percentage of oocytes and granulosa cells survive the cryopreservation and thawing procedures. The numbers of intact and partially intact follicles in the fresh and cryopreserved tissue were nearly identical. This is in accordance with our previous 
findings in animal experiments $[12,16,27]$ and the findings of other groups [13-15]. Freezing at $-20 \mathrm{C}$ yielded a significant and prominent loss of healthy follicles and partially intact follicles. Nevertheless, even with the use of this insufficient freezing method, some follicles survived this procedure, although few were completely intact. This showed that the LIVE/DEAD assay probably has a tendency to overestimate the amount of tissue that is actually live. Comparison between the LIVE/ DEAD assays for $-20 \mathrm{C}$ freezing and for slow freezing and cryoprotectant shows that the cut-off rate for intact follicles (complete with an oocyte and $>50 \%$ of the intact granulosa cells alive) is at approx. $85 \%$.

Although the LIVE/DEAD assay has a tendency to overestimate the survival rate of follicles, it presents a reliable and reproducible method to assess the survival of cryopreserved ovarian tissue. Retransplantation of cryopreserved ovarian tissue is only meaningful only when the LIVE/DEAD assay finds at least $85 \%$ of the follicles showing complete survival or a living oocyte and more than $50 \%$ granulosa cells alive.

\section{References}

1. Demeestere I, Simon P, Englert Y, Delbaere A. Preliminary experience of ovarian tissue cryopreservation procedure: alternatives, perspectives and feasibility. Reprod Biomed Online 2003; 7: 572579.

2. Siebzehnrubl E. Cryopreservation of ovarian tissue to preserve female fertility-state of the art. Andrologia 2003; 35: 180-181.

3. Aigner S, Van der Elst J, Siebzehnrubl E, Wildt L, Lang N, Van Steirteghem AC. The influence of slow and ultra-rapid freezing on the organization of the meiotic spindle of the mouse oocyte. Hum Reprod 1992; 7: 857-864.

4. Boiso I, Marti M, Santalo J, Ponsa M, Barri PN, Veiga A. A confocal microscopy analysis of the spindle and chromosome configurations of human oocytes cryopreserved at the germinal vesicle and metaphase II stage. Hum Reprod 2002; 17: 1885-1991.

5. Morice $\mathbf{P}$, Thiam-Ba R, Castaigne D, Haie-Meder C, Gerbaulet A, Pautier P, Duvillard P, Michel G. Fertility results after ovarian transposition for pelvic malignancies treated by external irradiation or brachytherapy. Hum Reprod 1998; 13: 660-663.

6. Blumenfeld Z. Gynaecologic concerns for young women exposed to gonadotoxic chemotherapy. Curr Opin Obstet Gynecol 2003; 15: 359-370.

7. Aubard Y, Poirot C, Piver P, Galinat S, Teissier MP. Are there indications for ovarian tissue cryopreservation? Fertil Steril 2001; 76: 414-415.

8. Donnez J, Bassil S. Indications for cryopreservation of ovarian tissue. Hum Reprod Update 1998; 4: 248259.

9. Liu HC, He Z, Rosenwaks Z. Mouse ovarian tissue cryopreservation has only a minor effect on in vitro follicular maturation and gene expression. J Assist Reprod Genet 2003; 20: 421-431.

10. Donnez J, Dolmans MM, Demylle D, Jadoul P, Pirard C, Squifflet J, Martinez-Madrid B, van Langendonckt A. Livebirth after orthotopic transplantation of cryopreserved ovarian tissue. Lancet 2004; 364: 1405-1410.

11. Meirow D, Levron J, Eldar-Geva T, Hardan I, Fridman E, Zalel Y, Schiff E, Dor J. Pregnancy after transplantation of cryopreserved ovarian tissue in a patient with ovarian failure after chemotherapy. $N$ Engl J Med 2005; 353: 318-321.

12. Maltaris $T$, Dimmler A, Muller A, Binder $\mathbf{H}$, Hoffmann I, Kohl J, Siebzehnrubl E, Beckmann MW, Dittrich R. The use of an open-freezing system with self-seeding for cryopreservation of mouse ovarian tissue. Reprod Domest Anim 2005; 40: 250254.

13. Gook DA, Edgar DH, Borg J, Archer J, McBain JC. Diagnostic assessment of the developmental potential of human cryopreserved ovarian tissue from multiple patients using xenografting. Hum Reprod 2005; 20: 72-78.

14. Martinez-Madrid B, Dolmans MM, Langendonckt AV, Defrere S, Van Eyck AS, Donnez J. Ficoll density gradient method for recovery of isolated human ovarian primordial follicles. Fertil Steril 2004; 82: 1648-1653.

15. Martinez-Madrid B, Dolmans MM, Van Langendonckt A, Defrere S, Donnez J. Freezethawing intact human ovary with its vascular pedicle with a passive cooling device. Fertil Steril 2004; 82: 1390-1394.

16. Siebzehnrubl E, Kohl J, Dittrich R, Wildt L. Freezing of human ovarian tissue-not the oocytes but the granulosa is the problem. Mol Cell Endocrinol 2000; 169: 109-111.

17. Thurston LM, Watson PF, Holt WV. Semen cryopreservation: a genetic explanation for species and individual variation? Cryo Letters 2002; 23: 255262.

18. Wolter TP, von Heimburg D, Stoffels I, Groeger A, Pallua N. Cryopreservation of mature human adipocytes: in vitro measurement of viability. Ann 
Plast Surg 2005; 55: 408-413.

19. Rubinsky B. Principles of low temperature cell preservation. Heart Fail Rev 2003; 8: 277-284.

20. LIVE/DEAD Viability/Cytotoxicity Kit for mammalian cells, Product Information, Molecular Probes, Invitrogen, August 2005.

21. Blatt J. Pregnancy outcome in long-term survivors of childhood cancer. Med Pediatr Oncol 1999; 33: 29 33.

22. Morita Y, Perez GI, Paris F, Miranda SR, Ehleiter D, Haimovitz-Friedman A, Fuks Z, Xie Z, Reed JC, Schuchman EH, Kolesnick RN, Tilly JL. Oocyte apoptosis is suppressed by disruption of the acid sphingomyelinase gene or by sphingosine-1phosphate therapy. Nat Med 2000; 10: 1109-1114.

23. Lobo RA. Potential options for preservation of fertility in women. N Engl J Med 2005; 353: 64-73.

24. Gook DA, McCully BA, Edgar DH, McBain JC. Development of antral follicles in human cryopreserved ovarian tissue following xenografting. Hum Reprod 2001; 16: 417-422.

25. Oktay K, Newton H, Mullan J, Gosden RG. Development of human primordial follicles to antral stages in SCID/hpg mice stimulated with follicle stimulating hormone. Hum Reprod 1998; 13: 11331138.

26. Schmidt KL, Byskov AG, Nyboe Andersen A, Muller J, Yding Andersen C. Density and distribution of primordial follicles in single pieces of cortex from 21 patients and in individual pieces of cortex from three entire human ovaries. Hum Reprod 2003; 18: 1158-1164.

27. Maltaris T, Kaya H, Hoffmann I, Mueller A, Beckmann MW, Dittrich R. Comparison of xenografting in SCID mice and LIVE/DEAD assay as a predictor of the developmental potential of cryopreserved ovarian tissue. In Vivo 2006; 20: 1116. 